\title{
Impact of Pandemic on Digital Economy Development in Russia
}

\author{
Subbotina T.A. \\ Yaroslav-the-Wise Novgorod State University, \\ Veliky Novgorod, Russia, \\ tatyana.subbotina@novsu.ru
}

\begin{abstract}
The article is devoted to the study of pandemic impact as a global process on digital economy development in Russia. Nowadays, this problem is more than ever relevant since we have met the process of economic recession resulted from restricting measures during the quarantine. Due to the current situation, the entire economy of the country was forced to go digital, in order to somehow support financial stability. Certain economic entities were not practically affected by the pandemic impact, but for the other ones, on the contrary, a digital mode became a determining development factor. Digital development level of a country determines its position in the global market. The Russian Federation has long been striving for information independence. Now, our country is not among the leaders in terms of the volume of digital economy in total GDP, though this parameter is growing every year. Thus, in 2010 the Information Society State Program was formed, and in 2019 the Digital Economy National Project was introduced. The author of this article considered the impact of the pandemic on the involvement of the Russian Federation population into digitalization, the development of digital economy during the pandemic and its projected development.
\end{abstract}

\section{Keywords-digital economy, pandemic, Russian Federation}

\section{INTRODUCTION}

At the moment, society is based on knowledge and intelligence. The transition of society to a new stage is conditioned by the civilization development, knowledge implementation which takes the form of economic products. This form is reflected in the digital economy.

In our life time such a resource as information becomes as important as any other production factor. Since antiquity, great philosophers tried to define the concept of technology. The world does not stand still, and computerization has been developing everywhere. This process has both positive and negative aspects. On the one hand, remote work is gaining popularity, art and culture go digital. On the other hand, certain occupations are being supplanted, and others no longer require human labor. Despite the civilization development, science still faces problems. One of them was the emergence of the global virus COVID-19.
In order to stay safe, all global residents were forced to stick to the mode of self-isolation and quarantine. The majority of life areas have moved to a new format - digital.

The Information Society State Program was introduced to improve the life quality of citizens, the country's competitiveness and the level of its development [1]. According to the reporting data on the Program's implementation, the actual values of parameters were close to the planned ones for a long time, but at the end of 2019 the values demonstrated a sharp deviation.

The Digital Economy National Project is a program of the Russian Federation Government, the purpose of which is to implement safe digital technologies for economic entities in the period from 2019 to 2024 [2].

Economic digitalization is a component of digital transformation that was planned to achieve by the Government of the Russian Federation (Fig. 1).

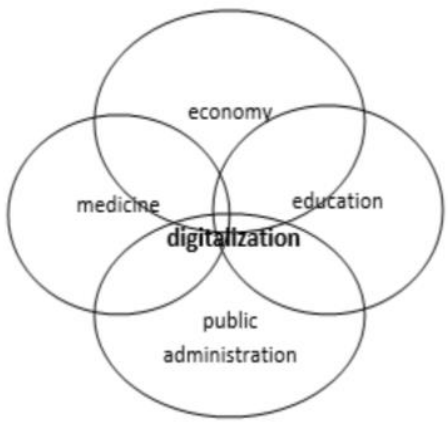

Fig. 1. Digital transformation process

By 2024, the state has planned to implement an integrated digital transformation of economic and social areas.

For this, a number of tasks is necessary to fulfill:

- develop legislature on digital technologies;

- transform digital infrastructure, introduce digital technologies in all key areas of economy and public administration; 
- organize training of personnel for the relevant process [3].

All life structures are interconnected, so the process of digital transformation should concern all components. This dependence was noted by Klaus Schwab, he meant timely production digitalization which should ultimately lead to society digital transformation.

Despite the unstable situation in the country, the National Program still actively develops. Thus, on May 22, 2020 the concept of law regulation within the digital economy developed by the Skolkovo Foundation became known. This concept proposes to introduce a preferential tax regime for entities engaged in the digital economy, as well as introduce a notion of digital educational environment and regulate a normative base for entities using digital technologies.

\section{PRoblem Statement}

Among all countries Russia takes the $11^{\text {th }}$ place in terms of the level of gross domestic product ( $\$ 1.699 .877$ million), of which the volume of sold domestic products in the field of information technologies in 2019 amounted to $\$ 24.18$ billion, this being by $7 \%$ more than in 2018 .

Pandemic is a global process. In most countries the COVID-19 affected all life areas. The pandemic resulted in global crisis, thereby the development of our country had to slow down its rate. Despite the projected decline in economic performance, the country's digital economy still develops.

In this research three periods are considered. The first period is that before the pandemic (the first quarter of 2019), the second period is the coronavirus pandemic (our time). The first two periods are compared throughout the research. The last period is predictable, in which the scenario of digital economy post-pandemic development in our country is considered (Fig. 2).

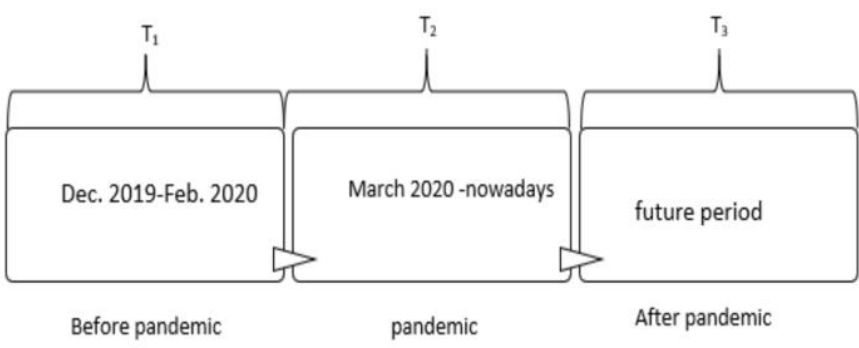

Fig. 2. Considered periods of digitalization process in the Russian Federation

The research problem is to determine the positive and negative impact of the pandemic on the country's digital economy.

\section{RESEARCH QUESTIONS}

The author suggests posing three questions for further discussion. This helps to build the working course by the best way, at this the answers obtained will be the research results.

1. How has the pandemic impacted the development of the digital economy in Russia?

2. In what way has this impact been reflected?

\section{How will the digital economy develop further?}

The following text is concerned with the above questions. The research results help to determine the development stage of the country, its competitiveness level in relation to other countries, and the future of the digital economy in the state.

The research subject is the pandemic impact on the country's digital economy.

The research object in this case is the digital economy of Russia.

When the research area has been selected, the exact purpose and research methods are determined.

\section{RESEARCH Methods AND PyRPOSE OF STYDY}

The following research methods were used:

1) information search:

- search for information about the state of digital economy in Russia in the pre-pandemic period;

- search for information about the state of digital economy at the present moment, under the conditions of the pandemic;

2) analysis and synthesis of data obtained:

- analysis of data on the use of digital economy tools by people and economic entities of the country before the pandemic;

- analysis of the digital development in the country during the pandemic;

- comparison of data obtained for these periods;

3) generalization of obtained data to summarize the research results.

It is now when all other resources are being exhausted that people search for information. The tasks of both the government and economic entities include maximum support for the digital economy development due to its need.

To estimate the significance of the digital economy, you just need to look around. Digital technologies are everywhere in our life: internet-resources, mobile network, technologies of virtual reality are all means of the digital economy.

The research purpose is to determine the pandemic impact on the digital economy development in the country.

The research problems are

- to study literature and news on the Digital Economy topic;

- to analyze the digital economy development in the Russian Federation;

- to assess the prospects for the digital economy development in the country.

\section{FINDINGS}

The most accurate concept of digital economy is given by Doctor of Economic Sciences Ivanov V.V., who defines it as a virtual environment which compliments reality. 
Periods of development of digital economy in the Russian Federation.

Before the pandemic, Russia had already experienced a rapid development of e-commerce. In 2019, $75.4 \%$ of the country's population had access to the Internet, namely 90 million, which is the largest indicator in Europe. The Germany Trade and Invest Journal characterized Russian digital companies as "inventive and flexible".

Digital transformation before the period of the pandemic was a priority of the scientific and technological development of the Russian Federation in accordance with the decree of the President of the Russian Federation dated 01.12.2016 No. 624 "On the strategy of scientific and technological development of the Russian Federation" [4].

\section{Digital economy of Russia in the pandemic period}

Although the integrated process of the digital transformations concerns all life areas, the economic sector has been mostly involved. The pandemic especially revealed this fact.

Firstly, being in quarantine and self-isolation, people began to use food delivery services more often. The demand in online stores also increased as the stationary departments were closed. The growth of sales was affected not only by the need for any things and food, but also by the psychological needs of people in a non-standard position. In other words, online shopping is a kind of stress therapy. Also, with the onset of the quarantine regime, the demand for food delivery increased by $50 \%$.

Secondly, the volume of transactions with plastic cards increased due to the following:

- online purchases most often require payment by electronic money or plastic cards;

- contactless payments reduce the risk of virus infection.

Along with the growth in demand, the supply from online stores has grown. In order not to go bankrupt, legal entities and individual entrepreneurs were forced to transfer trade to online mode, which, as a result, could help managers reduce costs. This type of trade is called a digital service. With such a model, a connection of the product-service type is formed between goods and services, at this the boundaries between material and non-material benefits are blurred. A digital trading format allows selling goods along with a number of services [5].

Along with the loss of jobs or temporary unemployment, people began to master new skills and professions [6]. Hence we have the growing popularity of freelance services. It can be noted that this is a positive effect of the pandemic on society. Far from the surrounding world, we can still develop thanks to digitalization. In favorable conditions such a situation can lead to the growth of demand on the labor market, personnel qualification increase, and the general society development.

One more significant aspect is the transition to remote work and education, this influencing essentially the demand for online resources.

Although the digital economy gave new chances for an ordinary consumer, the pandemic slowed down the working process for both Complex of Shared Use Centers engaged in creating and developing new technologies and other science intensive enterprises.

In connection with the coronavirus pandemic, the Analytical Center under the Government of the Russian Federation proposed to postpone the implementation of several projects of the Digital Economy program and redistribute the funds of the Information Security project to other program tasks.

Despite this, Gazprom Neft Company implemented the possibility of remote work for office employees, and a contactless electronic transmission system for rotational shifts was launched at oil refineries. The company also introduced the operation of automatic loading racks for oil products. Platforms for remote payment and digital production management have become demanded. Due to digitalization, the Company increases the efficiency of projects in terms of implementation time [7].

An important topic to be discussed is the simultaneous impact of two factors: prices decline for energy resources (oil) and decrease of business activities due to restricting measures as they impact the real incomes of people. This situation still more increases the digital inequality as people may simply not have enough money to obtain information. During the pandemic social risks based on the digital divide can be especially seen [8].

The pandemic period became a new developmental stage for protective assets [9]. Thus, according to the data of the VTB Bank, the growth of the best shares in the pharmaceutical and gold mining sectors amounted to $27.5 \%$ during the general fall.

The TGK-2 Company demonstrated the highest growth of share price $(50.9 \%)$, although short in duration.

Despite such indicators, the stock market of the Russian Federation declined. By INDEXCF indicator we can trace the decline trend of share prices of companies during the pandemic (Fig. 3).

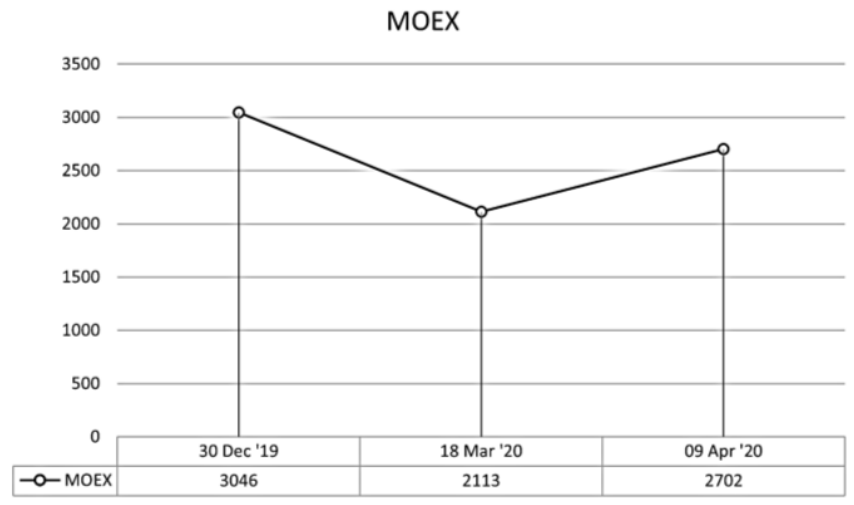

Fig. 3. Pandemic impact on INDEXCF alteration

Analyzing the obtained data, we can conclude that the pandemic caused the sharp decline of share prices of Russian companies (by 30.6\%), but in April the share prices began growing and increased by $22.2 \%$. At the moment, the highest index after the lifting of quarantine measures falls on August 13 and is 3098 rubles. 
A large share of investment in Russia is directed to the sector of industry, transport and communications, oil production. For the development of the digital space in the country, it is necessary to create an investment sector for digital technologies [10].

Financial analysts point out that the country was at the bottom of the recession in May, due to the pandemic impact. But this summer, after the lifting of restrictive measures, the economy began its recovery.

Small and medium-sized businesses continue to introduce digital tools into their work. The pandemic has highlighted digital gaps in the economic sector. The process of digitalization within companies should be introduced along with critical factors.

They include:

- cyber security;

- collective innovation strategies;

- development of lacking digital skills in personnel;

- alteration in company culture;

- setting norms and standards that determine the digital policy of a company;

- a person-centered approach;

- developing methods of flexible management [11].

But there is no a possibility to fulfill this list of factors due to limited means and time resulted from the situation in the country. Hence, the companies whose competent specialists could quickly adapt to rapidly changed conditions got the advantage.

You cannot also ignore global problems of pandemic impact on the world economy. Financing of states is threatened. COVID-19 mobilized the scientific community to develop new drugs and vaccines, but the enthusiasm will dry out when funding runs out [12].

The digital economy development requires certain funds, not every company can afford to go digital, hence in certain areas the digitalization process will slow down.

It should be noted that global economy suffers recession. Economic instability is characteristic of all developing countries [13]. Nowadays, crisis is characteristic of the majority of countries, even developed ones, as the pandemic affected the whole world.

Despite the certain difficulties, the pandemic helped societies to adapt and receive the digital economy.

The data obtained on the basis of the research results will be presented in the form of a table (Tab. 1).

The obtained results are evidence of ambiguous impact of the pandemic on the digital economy development in the country. As we have already noted, the advantage in this situation was gained by companies which had already been introducing digital technologies into the economic activities.

This state of implementation of the plan is forcing the Government to postpone the dates of the Digital Economy project to 2024. The main aim of the state is to restore the country's economy and support the population.

TABLE I - RESEARCH RESULTS

\begin{tabular}{|l|l|}
\hline \multicolumn{2}{|c|}{ Pandemic impact on digital economy of the country } \\
\hline \multicolumn{1}{|c|}{ Positive } & \multicolumn{1}{c|}{ Negative } \\
\hline $\begin{array}{l}\text { Accelerating the process of } \\
\text { digitalization of the population, their } \\
\text { introduction to technologies }\end{array}$ & $\begin{array}{l}\text { Slowing down the pace of } \\
\text { development of government } \\
\text { programs aimed at developing the } \\
\text { digital economy }\end{array}$ \\
\hline $\begin{array}{l}\text { Digital transformation of companies } \\
\text { in both small sectors and large } \\
\text { holding companies }\end{array}$ & $\begin{array}{l}\text { Losses of companies associated with } \\
\text { the closure of retail stores }\end{array}$ \\
\hline $\begin{array}{l}\text { People mastering new skills, demand } \\
\text { for online courses and trainings, } \\
\text { gradual transition to remote work }\end{array}$ & $\begin{array}{l}\text { Lack of state funds to support the } \\
\text { development of the digital economy } \\
\text { in the country }\end{array}$ \\
\hline $\begin{array}{l}\text { Development of digital services, } \\
\text { blurring the boundaries between } \\
\text { goods and services }\end{array}$ & $\begin{array}{l}\text { Decline in stock prices of companies, } \\
\text { which led to stagnation in the } \\
\text { economy }\end{array}$ \\
\hline $\begin{array}{l}\text { Development of digital culture for } \\
\text { both individuals and legal entities }\end{array}$ & $\begin{array}{l}\text { Exacerbating digital risks leading to } \\
\text { the digital divide }\end{array}$ \\
\hline
\end{tabular}

The country has launched the deployment of a digital platform for industry. Besides, the state allocates funds to develop state projects in the sphere of the digital economy.

The obtained data indicate that the Russian Federation is moving to a new level of development, namely computerized, though by a slow pace.

Digital economy of Russia after the pandemic period.

The research results demonstrate several areas for the further development of the digital economy in the pandemic period.

1. Small and medium enterprises have a choice of three digitalization areas (Fig. 4)

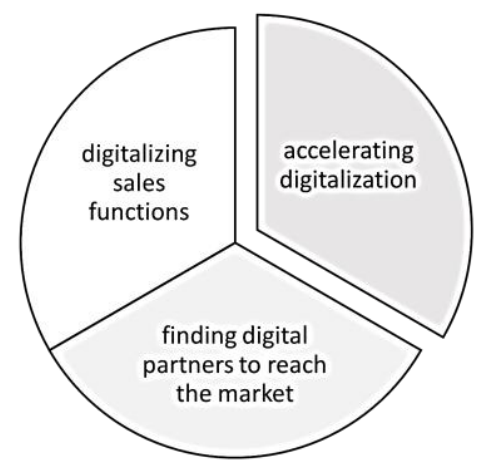

Fig. 4 Ways of digitalization for small and medium enterprises

The simultaneous combination of all three ways of development will be an optimal option. Thus, accelerating digitalization rate is necessary when moving to the organization of remote work. At the same time digitalization of sales is necessary today as it allows improving the quality of customer service and increasing the growth of sales [14].

The need for companies to permanently upgrade the development strategy using digital tool will emerge [15].

Russian companies should pay a special attention to agilemanagement which implies a flexible adaptation to constantly changing conditions [16]. 
2. At the level of the country's economic crisis, in large companies characterized by an optimal level of digital transformation conditioned by available information technologies there occurred a problem. Measures to combat coronavirus infection have led to the crisis in the country. Along with the fall of the Russian ruble, the demand for shares of Russian companies decreased. Companies are at risk of slowing down their digital development, without investment.

3. In all systems (healthcare, public administration, security, industry), a transformation of the labor market will take place, which will accelerate the elimination of traditional professions and increase the demand for new "professions of the future", as they are called [17].

Specialists in the field of digital technologies will need to be able to use digital tools, in particular those of virtual reality and the industrial Internet, be able to work in a remote format and be innovatively focused.

The pandemic helped identify the weak areas of the state. We have already known that funding for the digital economy will increase in the next three years. This arrangement of affairs indicates a serious intention of the state to develop the digital sphere.

\section{CONCLUSION}

In this research, the task was set to determine the impact of the pandemic on the development of the digital economy in the Russian Federation. During the course of the research we analyzed economic activities in the country.

Thanks to the obtained data, we can make the following conclusions.

The pandemic greatly impacted the digitalization process in the country, both in general and in particular: society, state, education and economy have been influenced.

In the arisen situation, the advantages were gained by those enterprises which had actively been introducing digital technologies into the economic process long before the pandemic onset. So, large companies have already had the factors needed for the rational digital transformation.

The pandemic impacted also the development of small business. It was small business that ran risk in the arisen situation. On the other hand, companies were enforced to carry out the digital transformation which will appear favorable if treated correctly.

Great shifts occurred in the digital development of society. Since life went digital, people were forced to interact remotely [18].

State programs for the introduction of digital technologies will continue to be implemented, since digital development is decisive for the country at the moment [19].

With the right approach, companies will be able to realize themselves through digital tools, expand and raise the level of digital culture, and gain access to the global market. Large holding companies will be able to improve the management structure and coordination of employees using telecommuting tools.

Thus, the impact of the global process on the development of the country was considered. Summing up, it is worth noting that, despite deviations from the plan caused by the pandemic, the digital economy in the country has entered a new stage, which determines the vector of its further development

\section{REFERENCES}

[1] G.S. Sologubova, Components of digital transformation: a monograph [Sostavlyayushchiye tsifrovoy transformatsii: monografiya], Moscow: Publisher Yurayt, 2020. (In Russ.).

[2] Reference legal system "Garant". On the State Program of the Russian Federation [O gosudarstvennoy programme Rossiyskoy Federatsii "Informatsionnoye obshchestvo (2011-2020)"], 2010. (In Russ.). Retrieved from https://base.garant.ru/199708

[3] N.A. Gorelov, and O.N. Korableva, Development of the Information Society: The Digital Economy: A Textbook for Universities [Razvitiye informatsionnogo obshchestva: tsifrovaya ekonomika: uchebnoye posobiye dlya vuzov], Moscow: Publisher Yurayt, 2020.

[4] V.I. Salygin, and A.S. Markin, "The digital economy in a pandemic" [Tsifrovaya ekonomika v usloviyakh pandemii], Scientific works of the VEO of Russia, 2020, vol. 223, pp. 244-250 (In Russ.). DOI: 10.38197/2072-2060-2020-223-3-244-250

[5] N.A. Shapiro, "Reasons for business recovery after the COVID-19 pandemic" [Osnovaniya dlya vosstanovitel'nogo rosta biznesa posle pandemii COVID-19], Scientific Journal of NRU ITMO. Series Economics and Environmental Management, 2020, vol. 2, pp. 58-64 (In Russ.). DOI: 10.17586/2310-1172-2020-13-2-58-64

[6] D.J. Deming, and K. Noray, "Earnings Dynamics, Changing Job Skills, and STEM Careers", The Quarterly Journal of Economics, 2020, vol. 135(4), pp. 1965-2005. DOI: https://doi.org/10.1093/qje/qjaa021

[7] A. Denisov, "Advanced science - first-class infrastructure" [Peredovoy_nauke_pervoklassnuyu_infrastrukturu], Trinity option Science, 2020, №7(301), pp. 4-5. (In Russ.). Retrieved from https://trvscience.ru/2020/04/denisov-skoltech

[8] I.E. Zhadan, "Social risks in the digital economy" [Sotsial'nyye riski v tsifrovoy ekonomike], Humanitarian Scientific Journal, 2018, vol. 1, pp. 20-26. (In Russ.). Retrieved from https://cyberleninka.ru/article/n/sotsialnye-riski-v-tsifrovoyekonomike/viewer

[9] Ch. Fleisher, How economists can help combat COVID-19, 2020 Retrived from https://www.aeaweb.org/research/epidemiologyeconomics-covid-response

[10] A.S. Minaylov, "Prospects for the development of the digital economy of Russia in the context of a pandemic" [Perspektivy razvitiya tsifrovoy ekonomiki Rossii v usloviyakh pandemii], Innovative science, 2020, vol. 6, pp. 105-107. (In Russ.). Retrieved from https://cyberleninka.ru/article/n/perspektivy-tsifrovoy-ekonomiki-rossiiv-usloviyah-pandemii/viewer

[11] L.A. Petrova, and T.E. Kuznetsova, "Digital technologies in economy and business" [Tsifrovyye tekhnologii v ekonomike i biznese], The Digital Economy, 2020, pp. 74-89. (In Russ.). DOI: 10.24411/20716435-2020-10014

[12] W. Zerhouni1, G.J. Nabel, and E. Zerhouni, "Patents, economics, and pandemics", Science, 2020, vol. 368(6495), pp. 1035. DOI: 10.1126/science.abc7472

[13] K. Shvab, Technologies of the fourth industrial revolution [Tekhnologii chetvertoy promyshlennoy revolyutsii], Moscow: Bombora, 2018. (In Russ.).

[14] E.J. Murray, "Epidemiology's Time of Need: COVID-19 Calls for Epidemic-Related Economics", Journal of economic perspectives, 2020 vol. 34(4), pp. 105-120 Retrived from https://www.aeaweb.org/articles?id=10.1257/jep.34.4.105

[15] R.I. Akmaeva, Possible development strategies of Russian companies in the post-crisis period $[\mathrm{O}$ vozmozhnykh strategiyakh razvitiya rossiyskikh kompaniy v postkrizisnyy period], Bulletin of the Astrakhan State Technical University. Series: Economics,2020, vol.2, pp. 7-18. (In Russ.). DOI: 10.24143/2073-5537-2020-2-7-18

[16] A. Priyono, A. Moin, and V.N.A.O. Putri, "Identifying Digital Transformation Paths in the Business Model of SMEs during the 
COVID-19 Pandemic", J. Open Innov. Technol. Mark. Complex, 2020, vol. 6(4), 104. DOI: https://doi.org/10.3390/joitmc6040104

[17] T. Smith Market rushes, 2020. Retrived from https://www.aeaweb.org/research/panics-frenzies-informationalefficiency-experiment

[18] E. Yu. Deputatova, "Rationalization of consumer behavior in the era of a pandemic" [Ratsionalizatsiya potrebitel'skogo povedeniya $\mathrm{v}$ epokhu pandemii], Economy and Business, 2020, vol. 4-2(62), pp. 69-72. DOI 10.24411/2411-0450-2020-10297

[19] D.E. Bloom, M. Kuhn, and K. Prettner, "Modern Infectious Diseases: Macroeconomic Impacts and Policy Responses", Journal of economic literature (Forthcoming), 2020. Retrived from https://www.aeaweb.org/articles?id=10.1257/jel.20201642 